\title{
Analisis pengaruh variabel ekonomi makro terhadap indeks harga saham gabungan periode 2015-2019
}

\author{
Dwi Annissa CRB, Ella, Endang Miftaqul K, Refo Putra S, Reinanda Putri, Imam Mukhlis* \\ Universitas Negeri Malang, Jl. Semarang No. 5 Malang, Jawa Timur, Indonesia \\ *Penulis korespondensi, Surel: imam.mukhlis.fe@um.ac.id
}

Paper received: 3-3-2021; revised: 24-3-2021; accepted: 28-3-2021

\begin{abstract}
Abstrak
Penelitian ini bertujuan untuk mengetahui variabel makro yang berpengaruh terhadap indeks harga saham gabungan pada periode 2015-2019 sehingga investor mempunyai pilihan untuk memberikan keputusan investasi saham. Penelitian ini menggunakan metode deskriptif kuantitatif dan disertai dengan pembuktian hasil. Populasi yang digunakan dalam penelitian ini adalah seluruh sampel yakni data IHSG tahun 2015 hingga tahun 2019 Teknik pengumpulan data yang digunakan dalam penelitian ini adalah melalui dokumentasi. Sedangkan jenis data yang digunakan adalah data sekunder yang diambil dari Badan Pusat Statistik (www.bps.go.id), website resmi Bank Indonesia (www.bi.go.id), dan website resmi OJK Indonesia (www.ojk.go.id). Teknik analisis data menggunakan analisis regresi linear berganda dengan bantuan alat analisis aplikasi STATA 16. Hasil penelitian ini menunjukkan bahwa variabel kurs dan jumlah uang beredar berpengaruh secara signifikan terhadap IHSG, sedangkan inflasi dan suku bunga tidak berpengaruh signifikan terhadap IHSG.
\end{abstract}

Kata kunci: saham; indeks harga saham gabungan; ekonomi makro; ordinary least square

\section{Pendahuluan}

Perubahan ekonomi makro di negara Indonesia tentu akan mempengaruhi perekonomian nasional yang tidak bisa lepas dari kegiatan investasi. Dapat dilihat dari inflasi yang tinggi dan melemahnya nilai tukar rupiah akan membuat banyak industri mengalami goncangan. Dengan jumlah produksi yang menurun akibat harga bahan baku yang terus naik yang dapat mengakibatkan menurunnya tingkat laba, yang akan berdampak pada turunnya harga saham di industri tersebut karena dividen yang akan diterima oleh investor menurun, sehingga banyak investor yang akan menarik investasi mereka. Selain itu, naiknya suku bunga akan membuat para investor lebih tertarik untuk berinvestasi dalam bentuk tabungan di bank daripada investasi di pasar modal.

Saham sebagai instrumen yang banyak diminati para investor akan selalu diperhatikan perkembangannya, karena mengandung risiko fluktuasi harga yang lebih tinggi bila dibandingkan dengan instrumen lain. Fluktuasi harga dalam pasar saham sudah seharusnya diperhatikan dengan serius oleh para investor. Menurunnya harga saham pada industri akan berdampak juga pada turunnya nilai Indeks Harga Saham Gabungan (IHSG) pada Bursa Efek Indonesia (BEI). Harga Saham Gabungan (IHSG) digunakan sebagai pedoman oleh investor dalam berinvestasi dan memantau tren pergerakan harga saham dan merupakan salah satu indikator untuk mengetahui perkembangan di pasar modal. Harga saham ditentukan menurut hukum permintaan dan penawaran atau kekuatan tawar menawar. Semakin banyak orang yang ingin membeli saham, maka harga saham tersebut cenderung bergerak naik. Berikut merupakan volume IHSG tahun 2015-2019.

This work is licensed under a Creative Commons Attribution-ShareAlike 4.0 International License. 
Jurnal Ekonomi, Bisnis dan Pendidikan, 1(3), 2021, 200-208

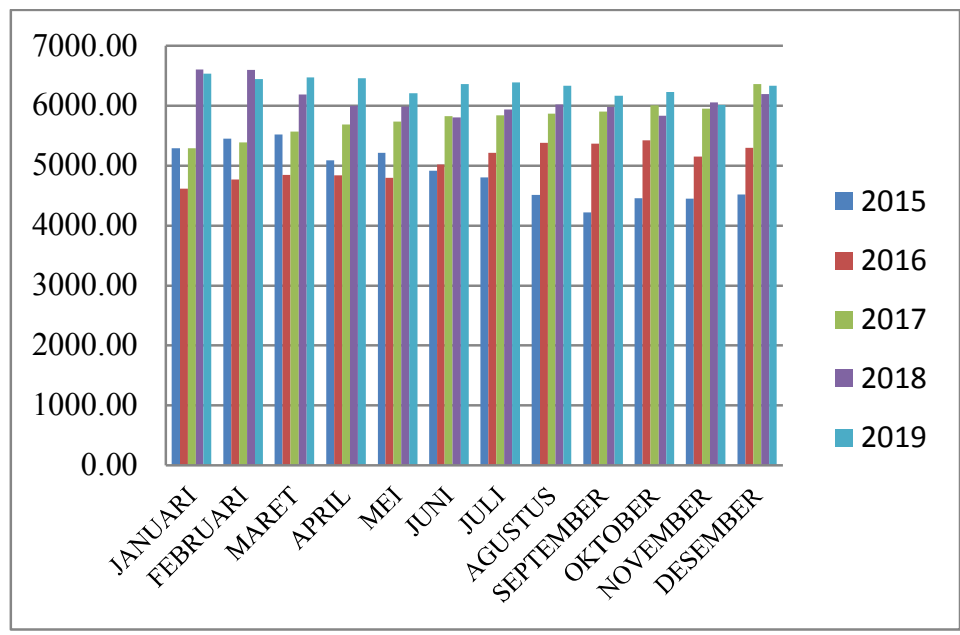

Fluktuasi yang terjadi di pasar modal akan terkait dengan perubahan yang terjadi pada berbagai variabel ekonomi makro (Tandelilin, 2010). Harga saham akan terpengaruh secara seketika oleh perubahan faktor ekonomi makro karena investor lebih cepat bereaksi terhadap dampak positif atau negatif dari perubahan faktor ekonomi makro. Dengan demikian, seorang investor harus dapat memahami pola perilaku pergerakan harga saham maupun nilai IHSG pada faktor-faktor eksternal dalam suatu negara yang dapat mempengaruhi pasar modal, sebelum melakukan investasi.

\subsection{IHSG}

Menurut Sunariyah (2006) indeks harga saham gabungan seluruh saham menggambarkan suatu rangkaian informasi historis mengenai pergerakan harga saham gabungan seluruh saham, sampai pada tanggal tertentu. Biasanya pergerakan harga saham tersebut disajikan setiap hari, berdasarkan harga penutupan di bursa pada hari tersebut. Indeks tersebut disajikan untuk periode tertentu. Pertambahan jumlah saham beredar berasal dari emisi baru, yaitu masuknya emiten baru yang tercatat di Bursa Efek, atau terjadi tindakan corporate action berupa split, right, waran, deviden saham, saham bonus, dan saham konversi.

Pengukuran kinerja perdagangan saham dalam penelitian ini di proxy dalam indeks harga saham gabungan (IHSG). Indeks biasa menjadi tolak ukur dalam memantau kecenderungan pasar dan perkembangan tingkat harga saham yang diperdagangkan. Indeks harga saham gabungan (IHSG) di BEI meliputi pergerakan harga untuk saham biasa dan saham preferen. IHSG diperkenalkan pertama kali pada 01 April 1983 dan selanjutnya menjadi indikator utama perdagangan saham di BEI.

Rumus yang digunakan untuk menghitung IHSG adalah sebagai berikut:

$I H S G=\frac{\text { Nilai Pasar } x 100}{\text { Nilai Dasar }}$

Notasi:

IHSG =Indeks Harga Saham Gabungan hari ke-t

Nilai Pasar = Jumlah lembar tercatat dibursa X harga pasar preferen pada hari ke-t

Nilai Dasar =Jumlah lembar tercatat dibursa X harga pasar perlembar saham biasa dan saham preferen yang mulai dari waktu dasar (10 Agustus 1982). 
Rumus untuk menyelesaikan nilai dasar awal sebagai berikut :

$N D B=\frac{N P L+N P T S}{N P L} \times 100$

Notasi:

NDB = Nilai dasar baru yang disesuaikan

NPL = Nilai pasar lama

NPTS = Nilai pasar tambahan saham

NDL = Nilai dasar lama

\subsection{Inflasi}

Inflasi adalah suatu kejadian yang menunjukkan kenaikan tingkat harga secara umum dan berlangsung secara terus - menerus. Laju inflasi merupakan tingkat perubahan secara umum untuk berbagai jenis produk dalam rentang waktu tertentu misalnya per bulan, per triwulan atau per tahun. (Murni, 2006). Menurut Sukirno (2004:333), berdasarkan sumber atau penyebab kenaikan harga-harga yang berlaku, inflasi biasanya dibedakan kepada tiga bentuk berikut: (1) Inflasi Tarikan Permintaan (Demand Pull Inflation), (2) Inflasi Desakan Biaya (Cost Push Inflation), (3) Inflasi Diimport. Menurut Rahardja dan Manurung (2004:164), ada beberapa indikator ekonomi makro yang digunakan untuk mengetahui laju inflasi selama satu periode tertentu, yaitu sebagai berikut: (1) Indeks Harga Konsumen (Consumer Price Index), (2) Indeks Harga Perdagangan Besar (Wholesale Price Index), (3). Indeks Harga Implisit (GDP Deflator)

Menurut Boediono (2001:162) inflasi dapat digolongkan menjadi dua golongan, golongan pertama didasarkan pada "parah" atau tidaknya inflasi tersebut, yaitu: (1) Inflasi Ringan (dibawah 10\% setahun), (2) Inflasi Sedang (antara 10-30\% setahun), (3) Inflasi Berat (30-100\% setahun), (4) Hiperinflasi (diatas 100\% setahun).

\subsection{Kurs}

Kurs adalah alat perbandingan nilai tukar mata uang suatu negara dengan mata uang negara asing atau perbandingan nilai tukar valuta antar negara (Hasibuan, 2005). Melemahnya rupiah berdampak buruk terhadap kegiatan konsumsi dan investasi karena dua hal. Pertama, memicu kenaikan harga barang impor dan inflasi, apalagi setelah kenaikan harga bahan bakar minyak (BBM) sehingga memikul daya beli dan konsumsi masyarakat. Kedua, kenaikan inflasi secara tajam akan memaksa Bank Indonesia (BI) menaikan suku bunga secara tajam (Manurung, 2008).

\subsection{BI Rate}

BI Rate adalah suku bunga kebijakan yang mencerminkan sikap atau stance kebijakan moneter yang ditetapkan oleh Bank Indonesia dan diumumkan kepada publik (www.bi.go.id). Bi Rate diumumkan oleh Dewan Gubernur Bank Indonesia setiap Rapat Dewan Gubernur bulanan dan diimplementasikan pada operasi moneter yang dilakukan Bank Indonesia melalui pengelolaan likuiditas (liquidity management) di pasar uang untuk mencapai sasaran operasional kebijakan moneter (www.bi.g.id). Sasaran operasional kebijakan moneter dicerminkan pada perkembangan suku bunga Pasar Uang Antar Bank Overnight (PUABO/N). 
Pergerakan di suku bunga PUAB ini diharapkan akan diikuti oleh perkembangan di suku bunga deposito, dan pada gilirannya suku bunga kredit perbankan (www.bi.go.id).

Menurut Sukirno (2002) di dalam teori, analisis mengenai penentuan tingkat suku bunga selalu menganggap bahwa dalam perekonomian hanya terdapat satu tingkat suku bunga. Namun, dalam kenyataannya keadaannya sangat berbeda. Tingkat bunga pinjaman pemerintah berbeda dengan tingkat bunga yang harus dibayarkan kepada konsumen. Dan bank mengenakan tingkat bunga yang berbeda-beda kepada nasabahnya. Perbedaan tersebut disebabkan oleh beberapa faktor antara lain: (1) Perbedaan risiko, (2) Jangka waktu peminjaman, (3) Biaya administrasi pinjaman.

Menurut Darmawi (2006) tingkat suku bunga merupakan salah satu indikator moneter yang mempunyai dampak dalam berbagai kegiatan perekonomian sebagai berikut: (1) Tingkat suku bunga akan mempengaruhi keputusan melakukan investasi yang pada akhirnya akan mempengaruhi tingkat pertumbuhan ekonomi. (2) Tingkat suku bunga juga akan mempengaruhi pengambilan keputusan pemilik modal apakah ia akan berinvestasi pada real asset ataukah pada financial asset. (3) Tingkat suku bunga akan mempengaruhi kelangsungan usaha pihak bank dan lembaga keuangan lainnya. (4) Tingkat suku bunga dapat mempengaruhi volume uang beredar.

\subsection{Jumlah Uang yang Beredar}

Menurut Bank Indonesia, jumlah uang beredar merupakan kewajiban dari otoritas moneter yang terdiri dari uang kertas dan uang logam yang berada di luar Bank Indonesia, serta simpanan giro bank umum dan sektor swasta domestik atau penduduk pada Bank Indonesia. M1 memiliki arti uang beredar dalam arti sempit, yaitu kewajiban sistem moneter yang terdiri dari uang kartal dan uang giral. Sedangkan M2 adalah pengertian uang dalam arti luas, yaitu kewajiban sistem moneter yang terdiri dari M1 dan uang kuasi (tabungan dan deposito berjangka dalam rupiah dan valas pada bank umum) (www.bi.go.id).

Perkembangan jumlah uang beredar mencerminkan atau seiring dengan perkembangan ekonomi. Biasanya bila perekonomian tumbuh dan berkembang, jumlah uang beredar juga bertambah, sedang komposisinya berubah. Bila perekonomian makin maju, porsi penggunaan uang kartal makin sedikit, digantikan uang giral atau near money. Biasanya juga bila perekonomian makin meningkat, komposisi M1 dalam peredaran uang semakin kecil, sebab porsi uang kuasi makin besar (Manurung Rahardja dalam Pengantar Ilmu Ekonomi).

\section{Metode}

\subsection{Jenis Penelitian}

Penelitian ini menggunakan metode kuantitatif deskriptif. Metode kuantitatif berguna untuk menghitung nilai saham gabungan yang direpresentasikan dengan IHSG dan data variabel independen (Inflasi, BI Rate, JUB, Kurs). Kemudian bersifat deskriptif karena mendeskripsikan hasil analisis. 


\subsection{Populasi dan Sampel}

Populasi penelitian merupakan kumpulan dari semua kemungkinan orang-orang, benda-benda, dan ukuran lain yang menjadi objek penelitian (Suharyadi, 2009). Populasi dalam penelitian ini adalah seluruh sampel yakni data IHSG tahun 2015 hingga tahun 2019.

\subsection{Teknik Pengumpulan Data}

Teknik pengumpulan data yang digunakan dalam penelitian ini adalah melalui dokumentasi, yaitu teknik pengumpulan data dengan cara mencari dokumen yang berisi datadata yang berhubungan dengan bahasan penelitian seperti data IHSG, Inflasi, Kurs, JUB dan BI Rate. Data yang digunakan dalam penelitian ini adalah data sekunder yang diambil dari website resmi Badan Pusat Statistik (www.bps.go.id), website resmi Bank Indonesia (www.bi.go.id), dan website resmi OJK Indonesia (www.ojk.go.id).

\subsection{Teknik Analisis Data}

Penelitian ini menggunakan teknik analisis deskriptif dan dalam melakukan analisis data menggunakan analisis regresi linear berganda dengan bantuan alat analisis aplikasi STATA 16. Analisis yang digunakan menggunakan pengujian asumsi klasik dan uji regresi dan hipotesis.

\section{Hasil dan Pembahasan}

\subsection{Hasil}

\subsubsection{Uji Asumsi Klasik}

\subsubsection{Uji Normalitas}

Dikatakan model regresi berdistribusi normal jika nilai probabilitas Shapiro-Francia lebih besar dari nilai signifikansinya $\alpha=5 \%$.

\begin{tabular}{lllll}
\hline Series & $\mathbf{W}^{\prime}$ & $\mathbf{V}^{\prime}$ & $\mathbf{z}$ & Prob $>\mathbf{z}$ \\
\hline Data Residual & 0.97019 & 1.793 & 1.117 & 0.13197 \\
\hline
\end{tabular}

Sumber: Data diolah Stata16

Berdasarkan uji normalitas diatas, probabilitas sebesar 0.13197 lebih besar dari 0.05 sehingga dapat disimpulkan data tersebut berdistribusi normal.

\subsubsection{Uji Multikolinearitas}

Uji multikolinearitas bertujuan untuk menguji ada tidaknya korelasi yang tinggi atau sempurna diantara variabel bebas yang terdapat pada model regresi.

\begin{tabular}{ll}
\hline Variabel & VIF \\
\hline JUB & 4.43 \\
Suku Bunga & 3.24 \\
Inflasi & 3.16 \\
Kurs & 3.09 \\
Mean VIF & 3.48 \\
\hline Sumber: Data diolah Stata16
\end{tabular}


Dari tabel hasil uji multikolinearitas dapat diketahui bahwa semua nilai VIF kurang dari 10. Hal ini dapat disimpulkan bahwa tidak terdapat multikolinearitas atau hubungan antar variabel bebas di dalam model regresi.

\subsubsection{Uji Heteroskedastisitas}

Model dikatakan tidak terdapat heteroskedastisitas apabila nilai signifikansi variabelnya lebih besar dari $\alpha=5 \%$

$$
\text { Chi2(1) }=1.26
$$

Sumber: Data diolah Stata16

$$
\text { Prob }>\text { chi } 2=0.2625
$$

Dalam penelitian ini uji heteroskedatisitas menggunakan metode Breusch-Pagan. Dikatakan tidak terjadi gejala heteroskedatisitas apabila "prob $>$ chi2" nilainya $>0.05$. Pada hasil uji heteroskedatisitas menunjukkan prob $>$ chi2 sebesar 0.2625 . Sehingga tidak terjadi heteroskedatisitas, karena $0.2625>0.05$.

\begin{tabular}{|c|c|c|c|c|}
\hline & \multicolumn{3}{|c|}{ Hasil analisis regresi } & \\
\hline & $\begin{array}{l}\text { R-Squared } \\
\text { Adjusted R-Squared } \\
\text { Prob F } \\
\text { Root MSE } \\
\end{array}$ & $\begin{array}{l}0.8 \\
0.7 \\
0.0 \\
297\end{array}$ & & \\
\hline Variabel & Coefficient & Std.Error & t-Statistic & Prob \\
\hline Kurs & -.4718766 & .1254477 & -3.76 & 0.000 \\
\hline Inflasi & 44.37622 & 50.08233 & 0.89 & 0.379 \\
\hline JUB & .001336 & .0001414 & 9.45 & 0.000 \\
\hline Suku Bunga & 2.495443 & 60.80988 & 0.04 & 0.967 \\
\hline Cons & 5047.136 & 1224.626 & 4.12 & 0.000 \\
\hline
\end{tabular}

\subsubsection{Uji Regresi dan Hipotesis}

Sumber: Data diolah Stata16

Bentuk Persamaan analisis regresi :

$Y=5047.136-.4718766+44.37622+.001336+2.495443+e$

\subsubsection{Uji Parsial}

(1) Nilai koefisien regresi dari nilai tukar adalah sebesar 0.4718766 dengan probabilitas sebesar 0.000. Karena nilai probabilitas kurang dari taraf signifikansi $(0.000<0.05)$, maka dapat diartikan variabel nilai tukar berpengaruh signifikan terhadap IHSG. (2) Nilai koefisien regresi dari inflasi adalah sebesar 44.37622 dengan probabilitas sebesar 0.379 . Karena nilai probabilitas lebih dari taraf signifikansi $(0.379>0.05)$, maka dapat diartikan variabel inflasi tidak berpengaruh signifikan terhadap IHSG. (3) Nilai koefisien regresi dari JUB adalah sebesar 0.001336 dengan probabilitas sebesar 0.000 . Karena nilai probabilitas kurang dari taraf signifikansi $(0.000<0.05)$, maka dapat diartikan variabel JUB berpengaruh signifikan terhadap IHSG. (4) Nilai koefisien regresi dari suku bunga adalah sebesar 2.495443 dengan probabilitas 
sebesar 0.967. Karena nilai probabilitas lebih dari taraf signifikansi (0.967 > 0.05), maka dapat diartikan variabel suku bunga tidak berpengaruh signifikan terhadap IHSG.

\subsubsection{Uji Simultan}

\section{Hasil Signifikansi}

\begin{tabular}{llll}
\hline Variabel & t-hitung & Sig t & Keterangan \\
\hline Kurs & -3.76 & 0.000 & Signifikan \\
Inflasi & 0.89 & 0.379 & Tidak Signifikan \\
JUB & 9.45 & 0.000 & Signifikan \\
Suku Bunga & 0.04 & 0.967 & Tidak Signifikan \\
\hline Sumber: Data diolah Stata16 & &
\end{tabular}

Pengujian hipotesis yang menyatakan ada pengaruh secara simultan nilai tukar dan JUB terhadap IHSG dapat dilihat dari hasil Uji F. Kriteria pengujian apabila nilai $p$ value $<0,05$, dapat disimpulkan bahwa $\mathrm{H}_{0}$ ditolak. Hasil uji simultan dapat dilihat pada tabel diatas.

(1) Dari hasil perhitungan tingkat signifikansi nilai tukar sebesar 0.000. ini berarti $\mathrm{H}_{0}$ ditolak, artinya bahwa ada pengaruh signifikan yang bersifat positif antara nilai tukar terhadap IHSG secara simultan. (2) Dari hasil perhitungan tingkat signifikansi inflasi sebesar 0.379. ini berarti $\mathrm{H}_{0}$ diterima, artinya bahwa tidak ada pengaruh signifikan antara inflasi terhadap IHSG. (3) Dari hasil perhitungan tingkat signifikansi JUB sebesar 0.000. ini berarti $\mathrm{H}_{0}$ ditolak, artinya bahwa ada pengaruh signifikan yang bersifat positif antara JUB terhadap IHSG secara simultan. (4) Dari hasil perhitungan tingkat signifikansi suku bunga sebesar 0.967. ini berarti $\mathrm{H}_{0}$ diterima, artinya bahwa tidak ada pengaruh signifikan antara suku bunga terhadap IHSG.

\subsubsection{Koefisien Determinasi}

Diketahui nilai koefisien determinasi (R-squared) sebesar 0.8018 yang berarti nilai tukar, Inflasi, JUB dan suku bunga mampu menjelaskan variasi IHSG sebesar 80,18\%. Sedangkan 19,82\% dipengaruhi oleh variabel-variabel lain di luar variabel yang digunakan dalam penelitian ini.

\subsection{Pembahasan}

Indeks Harga Saham Gabungan yang mencerminkan pergerakan keseluruhan harga saham perusahaan-perusahaan yang terdaftar di Bursa Efek Indonesia merupakan indikator yang dapat memberikan gambaran secara umum tentang perkembangan pasar modal di Indonesia, dimana kenaikan/penurunan angka indeks harga saham dalam suatu periode merupakan indikasi naik turunnya perkembangan pasar modal. IHSG merupakan suatu rangkaian historis mengenai pergerakan harga saham gabungan sampai pada tanggal tertentu dan biasanya pergerakan harga saham tersebut disajikan setiap hari perdagangan berdasarkan harga penutupan bursa pada hari tersebut.

Berdasarkan hasil uji hipotesis multivariate (Uji F) menunjukkan bahwa kurs mempunyai pengaruh yang signifikan terhadap IHSG yang berarti $\mathrm{H}_{0}$ ditolak, adanya kenaikan kurs atau nilai tukar akan mempengaruhi kenaikan IHSG secara simultan. . Hasil uji tersebut mendukung pengujian yang dilakukan oleh dari Rini Astuti, Joyce Lapian, dan Paulina Van Rate (2016) yang berjudul "Pengaruh Faktor Makro Ekonomi Terhadap Indeks Harga Saham 
Gabungan (IHSG) di Bursa Efek Indonesia (BEI) Periode 2006-2015" menunjukkan bahwa inflasi dan kurs berpengaruh positif signifikan terhadap IHSG, sedangkan suku bunga berpengaruh negatif signifikan terhadap IHSG.

Selanjutnya pengujian Uji F pada koefisien tingkat inflasi menunjukan bahwa tidak ada pengaruh signifikan tingkat inflasi dengan IHSG yang berarti $\mathrm{H}_{0}$ diterima. Hal ini bukan menjadi bahan pertimbangan investor untuk melakukan transaksi jual atau beli saham, karenanya investor tidak perlu mengkhawatirkan adanya perubahan pola pergerakan harga saham yang disebabkan pergerakan tingkat inflasi. Hasil uji tersebut mendukung pengujian yang dilakukan oleh Sebtian Dwi Prahesti dan R.A. Sista Paramita (2020) yang berjudul "Pengaruh Indeks SSEC, N225, STI, dan Faktor Makroekonomi Terhadap IHSG" menunjukkan bahwa variabel kurs dan STI berpengaruh terhadap IHSG. Sedangkan variabel inflasi, JUB, BI rate, The Fed, indeks SSEC, dan indeks Nikkei 225 tidak berpengaruh terhadap IHSG.

Kemudian pengujian Uji F terhadap koefisien JUB terhadap IHSG menunjukkan bahwa terdapat pengaruh yang signifikan yang berarti $\mathrm{H}_{0}$ ditolak. Adanya kenaikan jumlah uang yang beredar akan mempengaruhi kenaikan indeks harga saham gabungan.

Pengujian terakhir terhadap koefisien suku bunga terhadap IHSG dengan pengujian uji F menunjukkan bahwa tidak ada pengaruh yang signifikan yang berarti $\mathrm{H}_{0}$ diterima. Hal ini bukan menjadi bahan pertimbangan investor untuk melakukan transaksi jual atau beli saham, karenanya investor tidak perlu mengkhawatirkan adanya perubahan pola pergerakan harga saham yang disebabkan pergerakan tingkat suku bunga. Hasil uji tersebut mendukung pengujian yang dilakukan oleh Penelitian dari Iqbal Iman Zabidi dan Nadia Asandimitra (2018) yang berjudul "Pengaruh Inflasi, Kurs, Suku Bunga SBI, Dow Jones, dan Nikkei 225 Terhadap Indeks Harga Saham Gabungan pada Bursa Efek Indonesia Periode 2012-2016" menunjukkan bahwa variabel Dow Jones berpengaruh positif signifikan terhadap IHSG, sedangkan variabel inflasi, kurs, suku bunga SBI, dan Nikkei 225 tidak berpengaruh terhadap IHSG.

\section{Simpulan}

Berdasarkan hasil penelitian dan pembahasan analisis pada penelitian ini, dapat ditarik kesimpulan bahwa: (1) Analisis pengaruh variable makro yang diwakili nilai tukar (kurs) terhadap Indeks Harga Gabungan periode 2015-2019 dari hasil uji t dan hasil analisis multivariat kurs berpengaruh signifikan terhadap IHSG. (2) Analisis pengaruh variable makro yang diwakili inflasi terhadap Indeks Harga Gabungan periode 2015-2019 dari hasil uji t dan hasil analisis multivariat inflasi tidak berpengaruh signifikan terhadap IHSG. (3) Analisis pengaruh variable makro yang diwakili JUB terhadap Indeks Harga Gabungan periode 20152019 dari hasil uji t dan hasil analisis multivariat JUB berpengaruh signifikan terhadap IHSG. (4) Analisis pengaruh variable makro yang diwakili suku bunga terhadap Indeks Harga Gabungan periode 2015-2019 dari hasil uji t dan hasil analisis multivariat suku bunga tidak berpengaruh signifikan terhadap IHSG.

\section{Daftar Rujukan}

Anwar, K. (2010). Pengaruh Tingkat Inflasi, Suku Bunga Sbi, Kurs, Dan IHSG Terhadap Kinerja Reksadana Saham. Laporan Penelitian.

Astuti, R. (2016). Pengaruh faktor makro ekonomi terhadap indeks harga saham gabungan (IHSG) di Bursa Efek Indonesia (BEI) Periode 2006-2015. Jurnal Berkala Ilmiah Efisiensi, 16(2). 
Harsono, A. R., \& Worokinasih, S. (2018). Pengaruh Inflasi, Suku Bunga, dan Nilai Tukar Rupiah terhadap Indeks Harga Saham Gabungan (Studi pada Bursa Efek Indonesia Periode 2013-2017). Jurnal Administrasi Bisnis, 60(2), 102-110.

Husnul, H. M., Hidayat, R. R., \& Sulasmiyati, S. (2017). Analisis pengaruh inflasi, kurs (IDR/USD), produk domestik bruto dan harga emas dunia terhadap indeks harga saham gabungan (studi pada Indonesia periode 2008-2016). Jurnal Administrasi Bisnis, 53(1), 66-74.

Kurniawati, R., \& Khairunnisa, K. (2020). Analisis Faktor Makroekonomi yang Berpengaruh terhadap Indeks Harga Saham Gabungan (IHSG) Tahun 2010-2018. Jurnal Ilmiah MEA (Manajemen, Ekonomi, \& Akuntansi), 4(3), 1662-1684.

Megawati, N., \& Salim, M. N. (2019). Pengaruh Variabel Makroekonomi Terhadap Indeks Harga Saham Gabungan (IHSG). Media Ekonomi, 26(1), 47-54.

Mulyadi, M., \& Permata, I. S. (2020). Analisis makro ekonomi dan pasar keuangan global terhadap indeks harga saham gabungan. Jurnal Riset Manajemen dan Bisnis (JRMB) Fakultas Ekonomi UNIAT, 5(3), 261-272.

Otorima, M., \& Kesuma, A. (2016). Pengaruh nilai tukar, suku bunga, inflasi, jumlah uang beredar dan pdb terhadap indeks harga saham gabungan (ihsg) periode 2005-2015. Jurnal Terapan Manajemen Dan Bisnis, 2(2), 195539.

POETRA, R. P. (2016). Pengaruh Inflasi, Harga Minyak Mentah, Suku Bunga, Nilai Tukar Rupiah Terhadap Indeks Harga Saham Gabungan (Ihsg) Di Bursa Efek Indonesia. Jurnal Pendidikan Ekonomi (JUPE), 4(3).

Prahesti, S. D., \& Paramita, R. S. (2020). Pengaruh Indeks SSEC, N225, STI, Dan Faktor Makroekonomi Terhadap IHSG. Jurnal Ilmu Manajemen, 8(3), 878-893.

Prasetiono, D. W. (2012). Analisis Pengaruh Faktor Fundamental Ekonomi Makro dan Harga Minyak terhadap Saham Lq45 dalam Jangka Pendek dan Jangka Panjang. Journal of Indonesian Applied Economics, 4(1).

Prastowo, N. J. (2008). Dampak BI Rate Terhadap Pasar Keuangan: Mengukur Signifikansi Respon Instrumen Pasar Keuangan Terhadap Kebijakan Moneter (No. 21). Working Paper.

Reny, A. \& Yudhinanto. (2018). Analisis Pengaruh Suku Bunga SBI, Nilai Kurs, Harga Emas Dunia, Indeks Dow Jones, dan Indeks Hang Seng Terhadap IHSG (Studi Pada BEI Periode 2007-2016). JURNAL EKONOMI, 20(1), 67-81.

Rizky, I. A., Amin, M., \& Mawardi, M. C. (2019). Pengaruh nilai tukar, suku bunga sbi, inflasi, dan pertumbuhan gdp terhadap pergerakan ihsg di bursa efek indonesia. Jurnal Ilmiah Riset Akuntansi, 8(05).

Sari, A. P. (2019). Pengaruh Jumlah Uang Beredar dan Pertumbuhan Ekonomi Terhadap Kinerja Reksadana Saham. J-MAS (Jurnal Manajemen dan Sains), 4(2), 362-367.

Sartika, U. (2017). Pengaruh Inflasi, Tingkat Suku Bunga, Kurs, Harga Minyak Dunia Dan Harga Emas Dunia Terhadap IHSG Dan JII Di Bursa Efek Indonesia. Balance: Jurnal Akuntansi Dan Bisnis, 2(2), 285-294.

Sukamto, S. W. (2016). Pengaruh Inflasi, Suku Bunga, Dan Nilai Tukar Rupiah Terhadap Indeks Harga Saham Gabungan (IHSG) Di Bursa Efek Indonesia. Manajemen Bisnis, 6(2).

Sunardi, N., \& Ula, L. N. R. (2017). Pengaruh BI Rate, Inflasi Dan Kurs Terhadap Indeks Harga Saham Gabungan (IHSG). Jurnal Sekuritas: Saham, Ekonomi, Keuangan dan Investasi, 1(2), 27-41.

Wibowo, F., Arifati, R., \& Raharjo, K. (2016). Analisis Pengaruh Tingkat Inflasi, Suku Bunga Sbi, Nilai Tukar Us Dollar Pada Rupiah, Jumlah Uang Beredar, Indeks Dow Jones, Indeks Nikkei 225, Dan Indeks Hangseng Terhadap Pergerakan Indeks Harga Saham Gabungan (Ihsg) Periode Tahun 2010-2014. Journal of Accounting, 2(2).

Zabidi, I. I., \& Haryono, N. A. (2018). Pengaruh Inflasi, Kurs, Suku Bunga Sbi, Dow Jones, Dan Nikkei 225 Terhadap Indeks Harga Saham Gabungan Pada Bursa Efek Indonesia Periode 2012-2016. Jurnal Ilmu Manajemen (JIM), 6(4). 468-476. 